\title{
Ex vivo and in vitro poultry intestinal models to evaluate antimycotoxins additives
}

\author{
Vinicius Duarte ${ }^{1}$ (D) Adriano Olnei Mallmann² ${ }^{2}$ Camila Tonini ${ }^{1}$ (D) Diogo Liberalesso ${ }^{3}$ (D) \\ Cristiane Rosa da Silva ${ }^{1 \oplus}$ Cristina Tonial Simões ${ }^{1 \oplus}$ Luciane Tourem Gressler $^{4}(\mathbb{D}$ \\ Ana Paula Frederico Rodrigues Loureiro Bracarense ${ }^{5}$ (i) Carlos Augusto Mallmann ${ }^{1 *}$ (i)
}

${ }^{1}$ Laboratório de Análises Micotoxicológicas (LAMIC), Centro de Ciências Rurais, Universidade Federal de Santa Maria (UFSM), 97105-900, Santa Maria, RS, Brasil. E-mail: mallmann@lamic.ufsm.br. "Corresponding author.

${ }^{2}$ Pegasus Science, Santa Maria, RS, Brasil.

${ }^{3}$ Soluções Analíticas, Microbiológicas e Tecnológicas (SAMITEC), Santa Maria, RS, Brasil.

${ }^{4}$ Pesquisadora Veterinária Independente, Santa Maria, RS, Brasil.

${ }^{5}$ Laboratório de Patologia Animal, Universidade Estadual de Londrina (UEL), Londrina, PR, Brasil.

ABSTRACT: In vitro tests are performed to evaluate the efficacy of antimycotoxins additives (AMAs); nevertheless, such assays show a low correlation with in vivo trials, which are also required to determine AMAs' efficacy. In search of an alternative method, the current study investigated the use of an ex vivo technique. Six AMAs (AMA1 to AMA6) had their ability to reduce intestinal absorption of aflatoxin $B_{1}$ (AFB) evaluated. Jejunal explants were obtained from broilers and subjected to two treatments per AMA in Ussing chambers: T1 (control) - 2.8 mg/L $A F B_{1}$, and $T 2-2.8 \mathrm{mg} / \mathrm{LAFB}_{1}+0.5 \%$ AMA. AMAs were also tested in vitro to assess adsorption of AFB in artificial intestinal fluid. In the ex vivo studies, AMA1 to AMA6 decreased intestinal absorption of $A F B$, by $67.11 \%, 73.82 \%, 80.70 \%, 85.86 \%$, 86.28\% and $82.32 \%$, respectively. As for the in vitro results, AMA1 to AMA6 presented an adsorption of $99.72 \%, 99.37 \%, 99.67 \%$, 99.53\%, 99.04\% and 99.15\%, respectively. The evaluated ex vivo model proved useful in the assessment of AMAs. No correlation was reported between ex vivo and in vitro findings. Further studies are needed to elucidate the correlation between ex vivo and in vivo results seeking to reduce animal testing.

Key words: intestinal explant, Ussing chamber, broiler, aflatoxin $B_{1}$ mycotoxin binder.

Uso de modelos ex vivo e in vitro de intestino de aves para avaliar aditivos antimicotoxinas

RESUMO: Testes in vitro são realizados para avaliar a eficácia de aditivos antimicotoxinas (AAMs); entretanto, tais experimentos apresentam uma baixa correlação com ensaios in vivo, que também são exigidos para determinar a eficácia de AAMs. Em busca de um método alternativo, o presente estudo investigou o uso de uma técnica ex vivo. A capacidade de seis AAMs (AAM1 a AAM6) de reduzir a absorção intestinal de aflatoxina $B_{l}\left(A F B_{1}\right)$ foi avaliada. Explantes jejunais foram coletados de frangos de corte e submetidos a dois tratamentos por AAM em câmaras de Ussing: T1 (controle) - 2,8 mg/L AFB , e T2 - 2.8 mg/LAFB $+0,5 \%$ AAM. Os AAMs também foram testados in vitro para verificar a adsorção de $A F B_{1}$ em fluido intestinal artificial. Nos ensaios ex vivo, AAM1 ao AAM6 diminuíram a absorção intestinal de AFB , em 67,11\%, $73,82 \%, 80,70 \%, 85,86 \%, 86,28 \%$ e 82,32\%, respectivamente. Quanto aos achados in vitro, AAM1 ao AAM6 apresentaram adsorção de 99,72\%, 99,37\%, 99,67\%, 99,53\%, 99,04\% e 99,15\%, respectivamente. O modelo ex vivo avaliado mostrou-se eficiente na avaliação de AAMs. Não houve correlação entre os resultados ex vivo e in vitro. Estudos adicionais são necessários para definir a correlação entre achados ex vivo e in vivo na tentativa de reduzir os testes em animais.

Palavras-chave: explante intestinal, câmara de Ussing, frango de corte, aflatoxina $B_{l}$, ligante de micotoxina.

\section{INTRODUCTION}

Antimycotoxins additives (AMAs) are among the multiple approaches used to detoxify aflatoxin-contaminated feedstuffs (OGUZ, 2012). Not all commercially available AMAs have proven efficacy, which should be based on in vitro and in vivo findings (BRASIL, 2006; MALLMANN et al., 2007).
Most in vitro studies employ artificial biological fluids or other models mimicking the animal's gastrointestinal tract (GIT) (AVANTAGGIATO et al., 2003, 2007). Nonetheless, no significant correlation has been reported between in vitro and in vivo assessments (MALLMANN et al., 2007), and in vitro/in vivo extrapolation is a complex issue. Thus, in vivo analysis is essential 
to prove the efficacy of an AMA. However, animal experimentation has caused great concern regarding welfare and ethical aspects, so different techniques have been associated in order to reduce the number of specimens used (CHELI et al., 2015). In this scenario, the principles of the $3 \mathrm{Rs}$, namely Replacement, Reduction and Refinement, have provided a framework for performing more humane animal research (CLARK, 2019).

Ex vivo testing refers to experiments done in animal tissues subjected to external environment, with minimal changes in the natural conditions (BASSO \& BRACARENSE, 2013). This technique allows to obtain multiple explants from a single specimen, and has been associated with Ussing chambers (UC) to investigate the effect of mycotoxins, since UC is a valuable tool to measure gut integrity (THOMSON et al., 2019). The impact of mycotoxins on intestinal permeability (AWAD et al., 2007), intestinal occludin expression and direct damage to intestinal villi, as well as products capable of limiting mycotoxins effects (GARCIA et al., 2018; GEREZ et al., 2018), has been demonstrated through this method. YIANNIKOURIS et al. (2013) conducted the first ex vivo trial applying $\mathrm{UC}$ to evaluate two AMAs, a hydrated sodium calcium aluminosilicate (HSCAS) and a yeast cell wall (YCW), in live intestinal tissue of rats; the latter was more efficient in binding zearalenone (ZEN). Nevertheless, there are no reports in the relevant literature describing the use of this apparatus to evaluate AMAs efficacy using intestinal fragments of birds.

In light of the above, this study tested an ex vivo poultry model associated with UC to assess AMAs efficacy. Moreover, the obtained results were compared with in vitro findings.

\section{MATERIALS AND METHODS}

\section{Broilers and feed}

Feeds free of aflatoxins, fumonisins, ZEN, deoxynivalenol (DON) and T-2 toxin contamination (verified via high performance liquid chromatography tandem mass spectrometry, HPLC-MS/MS) were formulated following nutritional recommendations (COBB-VANTRESS, 2018) and offered to 60 broilers destined for human consumption during the starter (1-20 days) and grower (21-24 days) phases. A feeding design was followed so that twelve birds were sampled daily on the 24th day of life because of the number of UC available to conduct the trials. After cervical dislocation, intestinal samples were collected and immediately tested. As no animal experiment was performed, the Ethics Committee on Animal Use of the Federal University of Santa Maria (Santa Maria, Brazil) exempted the work from an approval.

\section{Mycotoxin and antimycotoxins additives}

A standard aflatoxin $\mathrm{B}_{1}\left(\mathrm{AFB}_{1}\right)$ was purchased from Sigma Aldrich (St. Louis, MO, EUA), diluted and used at 1.0 and $2.8 \mathrm{mg} / \mathrm{L}$ in in vitro and ex vivo trials, respectively. Such concentrations were used in earlier studies performing in vitro and in vivo analyses to assess the effect of mycotoxins and additives (JANSEN VAN RENSBURG et al., 2006; KOLAWOLE et al., 2019; MARCHIORO et al., 2013). Three types of AMAs were evaluated, totaling six commercially available products (names have been omitted to ensure confidentiality): 1) AMA1 and AMA2: HSCAS; 2) AMA3, AMA4 and AMA5: HSCAS+YCW association; and 3) AMA6: HSCAS+YCW and seaweed extracts association. The toxin and the AMAs were directly included in the solution inside the UC.

\section{In vitro methodology}

An in vitro assay was conducted with each AMA before ex vivo testing. The product was incubated with $\mathrm{AFB}_{1}$ at $1.0 \mathrm{mg} / \mathrm{L}$ (concentration normally used to assess AMAs in vitro) in an artificial intestinal solution at pH 6.0 (THE UNITED STATES PHARMACOPEIA, 1990). Based on recommendation of AMAs' suppliers, an inclusion rate of $0.5 \%$ was used (three replicates/AMA); calculation was made according to the volume of the solution in the chamber. The in vitro adsorption calculation was estimated from the difference between the fluid with the presence of AMA and the fluid without it using a QTrap 5500 HPLC-MS/MS System (Applied Biosystems, Foster City, CA, USA) equipped with a Turbo Ion Spray electrospray ionisation (ESI) source and a 1290 Series HPLC System (Agilent, Waldbronn, BadenWürttemberg, Germany).

\section{Ex vivo methodology}

Four intestinal explants with $2 \mathrm{~cm}$ were collected from each broiler, totaling 240 samples (40 samples/AMA). The intestine was opened along the mesenteric border to remove the digesta and washed with cold salty isotonic solution. A pilot study evaluated fragments of duodenum, jejunum and ileum to identify the portion with the best viability (assessed via histopathology after 120-min exposure in the UC). Passage of the toxin across the intestinal explant was also analyzed. Additionally, serosal and seromuscular layers were removed with micro tweezers and scalpels. 
Results indicated the jejunum with all its layers as the most suitable portion to perform the experiment.

Four pairs of UC (Easy Mount Ussing Chambers, Physiologic Instruments, San Diego, CA, USA) were used. Each chamber half was connected to one vessel containing the same volume of the buffer solution with equal mineral composition. Both vessels were bubbled with a blend of $95 \% \mathrm{O}_{2}$ and $5 \% \mathrm{CO}_{2}$, which maintained tissue oxygenation and also worked as a supporting gas for the recirculation of the solution in each chamber. The vessels were kept at $37{ }^{\circ} \mathrm{C}$ through warm water circulation in the coating around.

The intestinal segment was fixed on the slider between the apical and basolateral sides of the UC. Total area of intestinal contact with the mycotoxin-enriched solution, which corresponds to the free area where the explant is fixed, was 1.0 $\mathrm{cm}^{2}$ (Figure 1). The explants were subjected to two treatments per AMA (two replicates/treatment) in a block design: T1 (control) - $2.8 \mathrm{mg} / \mathrm{L}$ of $\mathrm{AFB}_{1}$; and $\mathrm{T} 2-2.8 \mathrm{mg} / \mathrm{L}$ of $\mathrm{AFB}_{1}+0.5 \%$ AMA. In vivo testing with $\mathrm{AMAs}$ routinely use $\mathrm{AFB}_{1}$ at $2.8 \mathrm{mg} / \mathrm{kg}$, hence the choice to replicate it in the ex vivo trials. The jejunal explant was subjected to the UC process for 120 min; a previously incubated solution with $\mathrm{AFB}_{1}$ and the AMA was included in two UC; in the other

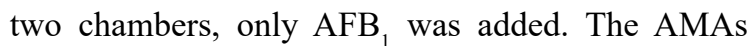
were incubated with $\mathrm{AFB}_{1}$ for $30 \mathrm{~min}$ prior to testing. The amount of $\mathrm{AFB}_{1}$ absorbed by the intestinal fragment was measured by HPLC-MS/MS; thus, it was possible to verify the intestinal capacity to absorb the mycotoxin either in the presence of an AMA or not. The following buffer solution (in $\mathrm{mmol} / \mathrm{L}$ ) was used for all the washings and incubations: $\mathrm{NaCl}-128, \mathrm{KCl}-4.7$, $\mathrm{CaCl}_{2}-2.5, \mathrm{KH}_{2} \mathrm{PO}_{4}-1.2, \mathrm{MgSO}_{4}-2.6, \mathrm{NaHCO}_{3}-$ 2.0 and D-glucose - 5.0; $\mathrm{pH}$ was maintained at 6.8.

\section{Mycotoxin extraction}

Immediately after the UC procedure, the explant was placed in a $15 \mathrm{ml}$ Falcon tube with 4 $\mathrm{ml}$ of a $\mathrm{AFB}_{1}$ extraction solution (acetonitrile:water $84: 16 \mathrm{v} / \mathrm{v}$ ) for $1 \mathrm{~h}$. Subsequently, it was macerated to increase contact surface with the solution to ensure complete extraction of the mycotoxin. The macerated
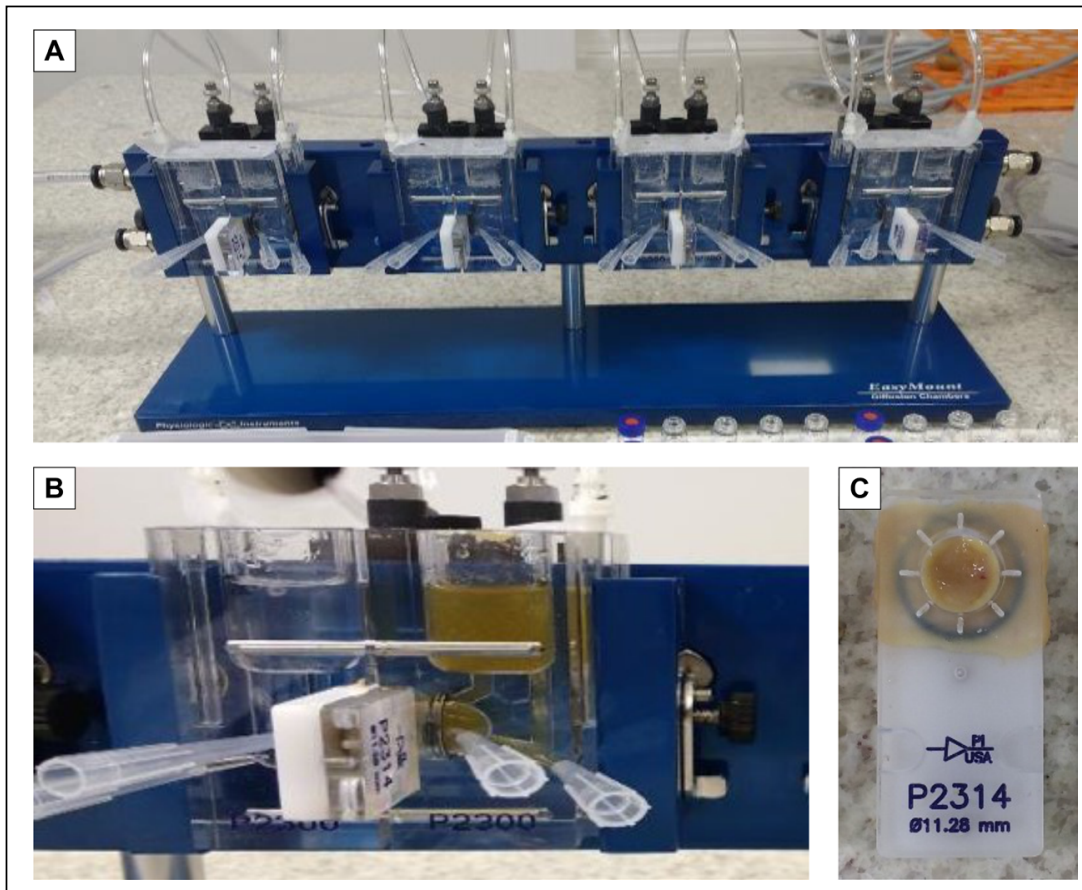

Figure 1 - Ussing chambers used in the ex vivo tests with jejunal explants of broilers. (A) General view of the equipment, which includes four Ussing chambers, with a heater block and $\mathrm{O}_{2}$ and $\mathrm{CO}_{2}$ circulation. (B) Close view of an Ussing chamber, showing the two chamber halves with the buffer solution and the substance under evaluation, separated by a piece where the tissue is fixed. (C) The slider, where the tissue is fixed by the steel pins. The slider is positioned between the two middle chambers, forming a barrier. 
tissue remained in contact with the solution for $1 \mathrm{~h}$, then it was removed and discarded. The tube was centrifuged (10 $\mathrm{min}, 2,058 \mathrm{xg}$ ), then the supernatant was collected and transferred to a $2 \mathrm{ml}$ Eppendorf tube which was also spun (10 $\mathrm{min}, 20,854 \mathrm{x} \mathrm{g}, 4^{\circ} \mathrm{C}$ ). The supernatant was transferred to another $2 \mathrm{ml}$ Eppendorf tube and this content constituted the sample which was diluted and injected into the HPLC-MS/MS system to determine the concentration of the mycotoxin.

\section{Performance parameters in HPLC-MS/MS analysis \\ Selectivity was obtained through the} addition of potentially interfering factors, both in blank and enriched samples. Linearity was obtained by developing a calibration curve consisting of seven concentration levels: 1, 2, 5, 10, 25, 50 and $100 \mu \mathrm{g} / \mathrm{L}$; each level had a specific solution prepared in triplicate. Instrumental readings were randomly performed. Linearity was observed by the graphic of the assays results, depending on the concentration of the analyte, and was verified based on the linear regression equation, which was determined by the least squares method.

The matrix effect was evaluated by establishing two calibration curves with seven levels each, as follows: a) calibration curve of the analyte in solution: formulated from pure analyte calibration standards in the solvent; and b) calibration curve of the blank matrix extract fortified with pure analyte calibration standards.

\section{Statistical analysis}

The number of blocks was set according to the test power criterion, with the aid of the software Gpower $3.1 .5^{\circ}$, using the means and standard deviations obtained in the pilot experiment. A test power of 0.99 was considered for the experimental design calculations. Statistical analyses were conducted using the software Statgraphics Centurion XV (Manugistics Inc., Rockville, USA). Data were subjected to ANOVA using the F Test at 5\%. Pearson's correlation was performed between the results obtained in the ex vivo and in vitro tests. Mean differences in the percentage of reduction in $\mathrm{AFB}_{1}$ absorption among the AMAs were separated using Tukey's HSD test.

\section{RESULTS}

\section{In vitro and ex vivo analyses}

This study originally aimed to measure $\mathrm{AFB}_{1}$ passage from the mucosal to the serosal side of the intestine, that is, from the apical to the basolateral side of the chamber, thus verifying the passage across the intestinal explant in the presence or absence of an AMA. Initial testing subjected an entire intestinal segment to the equipment; however, no significant $\mathrm{AFB}_{1}$ passage was observed. Afterwards, the seromuscular layer was removed and the explant was resubjected to $\mathrm{AFB}_{1}$; stripping was expected to allow the toxin to pass to the basolateral side, since it isolates the tissue from the outside, but passage through the serosal layer was not significant $(0.1$ to $0.5 \%)$.

The next step was to evaluate the concentration of $\mathrm{AFB}_{1}$ retained in the intestinal explant. Exposure to $\mathrm{AFB}_{1}$ in the presence or not of an AMA was then performed after having consolidated the technique in the UC with verification of intestinal absorption at different times (Figure 2).

The AMAs were able to bind $\mathrm{AFB}_{1}$ and prevent its absorption by the intestinal epithelium. There was a lower concentration of the toxin in the intestinal explant in the presence of all AMAs in comparison to the explant exposed to $\mathrm{AFB}_{1}$ alone $(\mathrm{P}<0.0001)$. AMA1 to AMA6 reduced the intestinal absorption of $\mathrm{AFB}_{1}$ by $67.11 \%, 73.82 \%, 80.70 \%$, $85.86 \%, 86.28 \%$ and $82.32 \%$, respectively $(\mathrm{P}<0.0001)$; there was a difference between additives in the ability to reduce intestinal absorption of $\mathrm{AFB}_{1}(\mathrm{P}<0.0001)$. In vitro data demonstrated an absorption ability of 99.72\%, 99.37\%, 99.67\%, 99.53\%, 99.04\% and $99.15 \%$, for AMA1 to AMA6, respectively; no significant difference was seen between the AMAs $(\mathrm{P}>0.05)$. No correlation (Pearson's correlation, $\mathrm{P}>0.05$ ) was found between ex vivo and in vitro findings; so, even though the AMAs presented an adsorption above $99 \%$ in the in vitro trials, a different pattern was observed in the ex vivo assays (Table 1).

\section{Performance of HPLC-MS/MS analysis}

The sample matrix may contain elements which interfere in the measuring performance and may increase/decrease the result. In this study, selectivity was verified by comparing the signs coming from the reading of the processed sample and the analyte of interest. There was no statistically significant difference regarding the impact of the matrix on $\mathrm{AFB}_{1}$ recovery $(\mathrm{P}>0.05)$. The $\mathrm{r}$ value for $\mathrm{AFB}_{1}$ was 0.9971 (Table 2).

Linearity evaluation was performed by the visual inspection of the linear regression chart of the calibration curves with and without matrix. A linear correlation coefficient $\left(R^{2}\right)$ over 0.99 was considered as ideal. The regression equation used to determinate the line was $y=a x+b$ (Figure 3). 


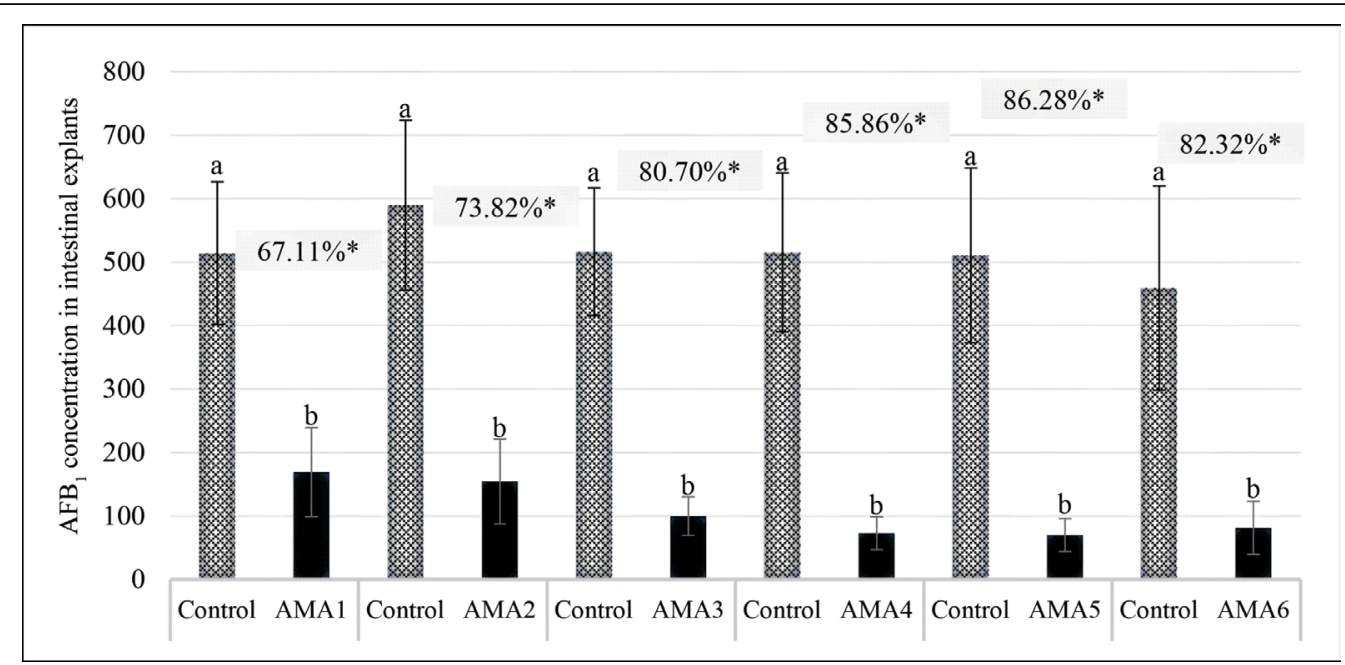

Figure 2 - Aflatoxin $\mathrm{B}_{1}$ concentration in jejunal explants of broilers in the presence or absence of antimycotoxins additives.AFB : aflatoxin $\mathrm{B}_{1}(\mu \mathrm{g} / \mathrm{kg})$; AMA1-6: antimycotoxins additives 1 to 6 ; a-b: means with different letters in the same trial indicate significant difference $(\mathrm{F}$ test; $\mathrm{P}<0.0001)$; "reduction in $\mathrm{AFB}$ intestinal absorption in the presence of each AMA.

\section{DISCUSSION}

These findings are in line with those disclosed by YIANNIKOURIS et al. (2013), who used UC mounted with intestinal segments of rats and subjected them to ZEN challenge. The authors reported that the mycotoxin concentration in the tissue was almost the same as that in the chamber, indicating that ZEN concentration gradient was maintained from the basolateral side into the tissue. Nevertheless, passage of ZEN to the serosal side was restricted $(0.4 \%)$. The researchers suggested that such behavior could be associated with the lipophilic properties of ZEN, which may lead to an interaction with the lipidic membranes of the intestinal epithelium and cause its encapsulation.

Another study also reported no significant toxin passage to the serosal side of jejunum when assessing DON transport across swine intestines (HALAWA et al., 2013). Pigs received feed containing DON $(0,4$ or $8 \mathrm{ppm})$ and were slaughtered to obtain explants to be mounted on UC; DON (4 or

Table 1 - Results of ex vivo and in vitro tests evaluating six antimycotoxins additives against aflatoxin $\mathrm{B}_{1}$ in broilers.

\begin{tabular}{|c|c|c|c|c|c|}
\hline \multirow[t]{2}{*}{ AMAs } & \multicolumn{3}{|c|}{ 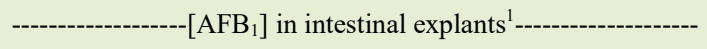 } & \multirow[t]{2}{*}{ Ex vivo ${ }^{2}$} & \multirow[t]{2}{*}{ In vitro ${ }^{3}$} \\
\hline & $\begin{array}{l}\text { Control } \\
(\mathrm{n}=20)\end{array}$ & $\begin{array}{l}\text { AMAs } \\
(\mathrm{n}=20)\end{array}$ & SEM & & \\
\hline 1 & $514.19^{a}$ & $169.11^{\mathrm{b}}$ & 43.86 & $67.11 \%{ }^{\mathrm{C}}$ & $99.72 \%$ \\
\hline 2 & $589.85^{\mathrm{a}}$ & $154.42^{\mathrm{b}}$ & 53.97 & $73.82 \%^{\mathrm{BC}}$ & $99.37 \%$ \\
\hline 3 & $516.50^{\mathrm{a}}$ & $99.69^{b}$ & 48.97 & $80.70 \%{ }^{\mathrm{AB}}$ & $99.67 \%$ \\
\hline 4 & $515.41^{\mathrm{a}}$ & $72.89^{b}$ & 51.94 & $85.86 \%{ }^{\mathrm{A}}$ & $99.53 \%$ \\
\hline 5 & $510.73^{\mathrm{a}}$ & $70.05^{\mathrm{b}}$ & 53.19 & $86.28 \%{ }^{\mathrm{A}}$ & $99.04 \%$ \\
\hline 6 & $459.23^{\mathrm{a}}$ & $81.21^{\mathrm{b}}$ & 49.50 & $82.32 \%{ }^{\mathrm{A}}$ & $99.15 \%$ \\
\hline SEM & & & & 1.130 & 0.084 \\
\hline
\end{tabular}

AMAs1-6: antimycotoxins additives 1 to 6 ; SEM: standard error of the mean; ${ }^{1}\left[\mathrm{AFB}_{1}\right]$ : aflatoxin $\mathrm{B}_{1}$ concentration (in $\mu \mathrm{g} / \mathrm{kg}$ ); ${ }^{2}$ reduction in $\mathrm{AFB}_{1}$ absorption by the intestine in the presence of the AMAs; ${ }^{3}$ adsorption of $\mathrm{AFB}_{1}$ by the AMAs in intestinal fluid (pH 6 ). ${ }^{\mathrm{a}, \mathrm{b}}$ means with different letters between columns differ significantly ( $\mathrm{F}$ test; $\mathrm{P}<0.0001$ ). ${ }^{\mathrm{A}, \mathrm{B}, \mathrm{C}}$ means with different letters between lines differ significantly (Tukey's test; $\mathrm{P}<0.0001$ ). 
Table 2 - Matrix effect on aflatoxin $\mathrm{B}_{1}\left(\mathrm{AFB}_{1}\right)$ recovery from intestinal samples of broilers.

\begin{tabular}{|c|c|c|c|c|c|c|c|}
\hline \multirow[t]{2}{*}{ Level } & \multirow{2}{*}{$\begin{array}{c}\text { Expected } \\
(\mu \mathrm{g} / \mathrm{L})\end{array}$} & \multirow{2}{*}{ Triplicate 1} & \multirow[b]{2}{*}{ Triplicate 2} & \multirow[b]{2}{*}{ Triplicate 3} & \multirow[b]{2}{*}{ Mean } & \multirow[b]{2}{*}{ SD } & \multirow[b]{2}{*}{$\%$ Precision } \\
\hline & & & & & & & \\
\hline 1 & 1 & 1.07 & 1.12 & 1.17 & 1.12 & 0.05 & 112.00 \\
\hline 2 & 2 & 2.12 & 1.95 & 1.71 & 1.93 & 0.20 & 96.33 \\
\hline 3 & 5 & 5.53 & 4.72 & 5.02 & 5.09 & 0.41 & 101.77 \\
\hline 4 & 10 & 10.20 & 9.31 & 9.95 & 9.82 & 0.46 & 98.20 \\
\hline 5 & 25 & 26.90 & 23.80 & 23.40 & 24.70 & 1.91 & 98.87 \\
\hline 6 & 50 & 55.30 & 47.60 & 47.10 & 50.00 & 4.59 & 100.13 \\
\hline 7 & 100 & 102.00 & 94.70 & 93.60 & 96.77 & 4.56 & 100.10 \\
\hline \multirow{2}{*}{ Level } & \multirow{2}{*}{$\begin{array}{l}\text { Expected } \\
(\mu \mathrm{g} / \mathrm{L})\end{array}$} & \multicolumn{6}{|c|}{ 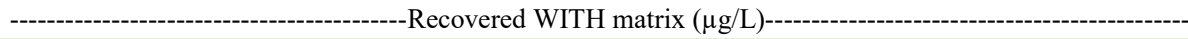 } \\
\hline & & Triplicate 1 & Triplicate 2 & Triplicate 3 & Mean & $\mathrm{SD}$ & \% Precision \\
\hline 1 & 1 & 0.81 & 1.18 & 1.03 & 1.01 & 0.18 & 100.53 \\
\hline 2 & 2 & 1.96 & 2.14 & 1.90 & 2.00 & 0.12 & 100.07 \\
\hline 3 & 5 & 5.10 & 5.43 & 4.71 & 5.08 & 0.36 & 101.70 \\
\hline 4 & 10 & 1020 & 10.30 & 9.48 & 9.99 & 0.44 & 99.93 \\
\hline 5 & 25 & 23.90 & 24.20 & 23.50 & 23.87 & 0.35 & 95.47 \\
\hline 6 & 50 & 49.90 & 50.90 & 48.50 & 49.77 & 1.20 & 99.63 \\
\hline 7 & 100 & 102.00 & 103.00 & 99.30 & 101.43 & 1.91 & 101.43 \\
\hline
\end{tabular}

SD: standard deviation. There was no significant difference between the use of matrix or not in $\mathrm{AFB}_{1}$ recovery (Tukey's test; $\left.\mathrm{P}>0.05\right)$.

$8 \mathrm{ppm}$ ) was introduced to the mucosal side, then the flux rate was evaluated in the specimens that had or not received the contaminated feed. There was a low flux rate in mucosal-to-serosal direction, but the DON-fed animals showed greater permeation due to the damage the toxin had caused in vivo. The authors raised two possibilities to explain these findings: DON metabolism in the jejunal epithelia or its accumulation in the tissues.

Conversely, AWAD et al. (2007) mounted chicken jejunum on UC and evaluated the flux rate of DON from the mucosal to the serosal side at 30,60, 90 and $120 \mathrm{~min}$. There was $6.3 \%$ passage at $120 \mathrm{~min}$, which is higher than that registered herein. A review of the relevant literature did not disclose any results about $\mathrm{AFB}_{1}$ passage through intestinal explants of birds using UC.

With respect to the removal of the seromuscular layer of the intestine described here, stripping was highly detrimental; the villi and the tissue structure were damaged, so the explant could not be used in the UC. Such data are in agreement with those reported when evaluating the viability of employing the UC to determine jejunal permeability of highly permeable compounds in several species; tissues were histologically analyzed before and after using the apparatus (NEIRINCKX et al., 2010).
Dissection of the jejunal seromuscular layer of turkeys, dogs, pigs and horses indicated the intestines of the two first species as inadequate for permeability evaluations. Moreover, attempts to remove the jejunal tissue of birds failed due to mucosal damage. The authors stated that intense epithelial damage and accumulation of mucus and cellular debris in the lumen are accountable for the low and greatly variable permeability across the jejunum of turkeys and dogs; the intestine of the pigs, in turn, was highly permeable. The findings observed in birds were attributed to the longer villi, the existence of wider and more numerous tight junctions facilitating paracellular transport, and the greater concentration and secretion rate of bile salt in this species.

Despite being scarce, literature reports indicate a low rate of mycotoxins passage through intestinal explants of birds (HALAWA et al., 2013) as well as a low tissue viability after stripping (NEIRINCKX et al., 2010), thus leading to unreliable outcomes. In view of that, the present investigation measured the amount of mycotoxin absorbed by the entire structure of the intestinal epithelium with all its layers intact.

As to efficacy tests, AMAs had a high percentage of adsorption in vitro and prevented absorption of the toxin. Nonetheless, the fact that 


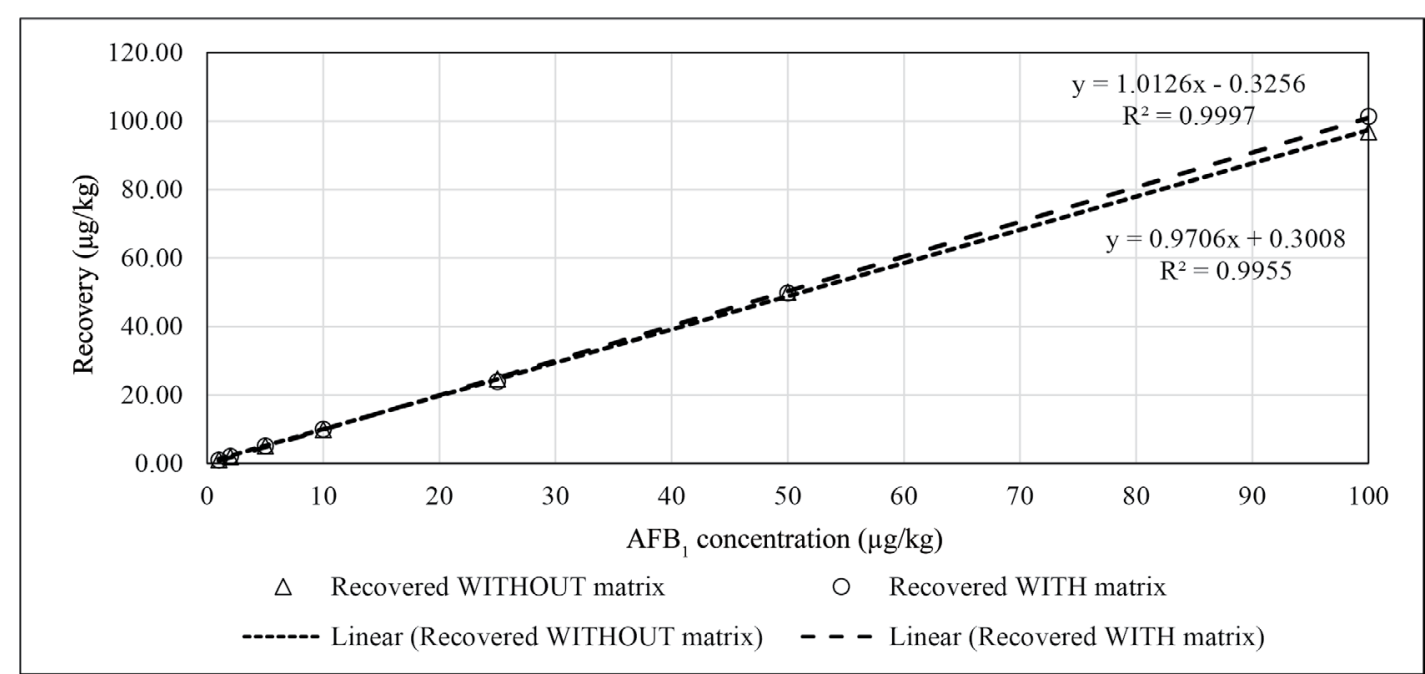

Figure 3 - Linearity of the curves of aflatoxin $\mathrm{B}_{1}\left(\mathrm{AFB}_{1}\right)$ recovery with and without the matrix.

they did not demonstrate the same percentage of adsorption when tested ex vivo must be highlighted, indicating that $\mathrm{AFB}_{1}$ presented a greater affinity for the epithelium than for the AMAs. All AMAs showed an in vitro adsorption over $99 \%$, while reduction in intestinal absorption of $\mathrm{AFB}_{1}$ ranged from $67.11 \%$ to $86.28 \%$; this may explain the differences commonly observed between in vitro and in vivo results: products which have an excellent in vitro efficacy show little or no efficacy in vivo. So, when included in animal feed, the AMA does not have the same potential to reduce the concentration of the toxin as it does in vitro, demonstrating that interaction of the toxin with the epithelium is more complex than the in vitro simulation of the intestinal juice.

The European Food Safety Authority (EFSA, 2010) reinforces these data: in vitro assays are considered a viable tool to analyze the potential of AMAs to act in mycotoxin control and may be used to provide information about their mechanism of action. Nevertheless, it mentions that such tests do not fully represent the conditions of the GIT and the differences between the target-animals and their metabolism and, consequently, must not be employed to demonstrate the efficacy of an AMA under natural conditions.

An in vitro model simulating the swine GIT was firstly used to evaluate the potential of activated carbon and cholestyramine to adsorb ZEN (AVANTAGGIATO et al., 2003). The method consists of four successive compartments simulating the stomach, duodenum, jejunum and ileum. The potential of several AMAs to adsorb or inactivate mycotoxins was demonstrated by using simulations of the gastric, biliary and pancreatic secretions as well as bicarbonate to control the compartmental $\mathrm{pH}$ (AVANTAGGIATO et al., 2003, 2004, 2007).

The explants technique has recently been improved. ZHANG et al. (2017) mounted ileal fragments of broilers which had been damaged by Clostridium perfringens in vivo on UC and found a protective effect of dietary L-arginine upon the intestinal barrier. Another assessment used jejunal explants of piglets and showed Lactobacillus rhamnosus $\mathrm{RC} 007$ to be a promising AMA due to its ability to reduce DON toxicity (GARCIA et al., 2018). The same methodology was applied to evaluate DON's effect on intestinal explants of swine, and the ability of low doses of a chito-oligosaccharide to lessen the toxin's effects (GEREZ et al., 2018); the product was not able to avoid DON-induced damage.

Different results have been achieved in in vitro and ex vivo models applied to evaluate the adsorbent effect of a blend of probiotics (Lactobacillus and Propionibacterium) on AFB $_{1}$ in broilers (GRATZ et al., 2005). The adsorption potential obtained in vitro ranged from $57 \%$ to $66 \%$, while in the ex vivo assay it was $25 \%$; nonetheless, the ex vivo technique referred to animals' anaesthesia, ligature of a jejunal segment and injection of the toxin and probiotics. Another research evaluated the effects of DON upon intestinal morphology and activation of the mitogen activated protein kinases (MAPK) through in vivo and ex vivo models (LUCIOLI et al., 2013); results indicated the latter approach as a valuable tool to 
assess gastrointestinal toxicity after exposure to low doses of toxins.

This is the first report on the use of UC to evaluate AMAs' efficacy employing intestinal explants of broilers. This ex vivo model proved valuable in the assessment of AMAs, and further studies are required to establish the correlation between the present technique and in vivo studies.

\section{ACKNOWLEDGEMENTS}

C. A. Mallmann is grateful for the fellowship of research productivity (PQ; grant number 310190/2018-5) awarded by the Conselho Nacional de Desenvolvimento Científico e Tecnológico (CNPq, Brazil). A. P. F. R. L. Bracarense also acknowledges $\mathrm{CNPq}$ for her fellowship of PQ. This study was financed in part by the Coordenação de Aperfeiçoamento de Pessoal de Nível Superior (CAPES), Brazil - Finance code 001, in the form of $\mathrm{PhD}$ fellowships granted to C. Tonini and C. T. Simões. The authors thank the Soluções Analíticas, Microbiológicas e Tecnológicas (SAMITEC, Brazil) for technical support.

\section{DECLARATION OF CONFLICT OF INTEREST}

The authors declare no conflict of interest. The founding sponsors had no role in the design of the study; in the collection, analyses, or interpretation of data; in the writing of the manuscript, and in the decision to publish the results.

\section{AUTHORS' CONTRIBUTIONS}

V. Duarte: Conceptualization; Investigation; Methodology. A. O. Mallmann: Formal analysis; Investigation. C. Tonini: Formal analysis; Investigation. D. Liberalesso: Investigation. C. R. da Silva: Investigation. C. T. Simões: Formal analysis. L. T. Gressler: Writing-original draft; Writing-review \& editing. A. P. F. R. L. Bracarense: Writing-review \& editing. C. A. Mallmann: Conceptualization; Funding acquisition; Resources; Supervision.

\section{REFERENCES}

AVANTAGGIATO, G.; et al. Assessing the zearalenone-binding activity of adsorbent materials during passage through a dynamic in vitro gastrointestinal model. Food and Chemical Toxicology, v.41, p.1283-1290, 2003. Available from: $<$ https://europepmc.org/ article/med/12909260>. Accessed: Jan. 15, 2020. doi: 10.1016/ s0278-6915(03)00113-3.

AVANTAGGIATO, G.; et al. Evaluation of the intestinal absorption of deoxynivalenol and nivalenol by an in vitro gastrointestinal model, and the binding efficacy of activated carbon and other adsorbent materials. Food and Chemical Toxicology, v.42, p.817-824, 2004. Available from: <https://pubmed.ncbi.nlm.nih.gov/15046828/>. Accessed: Jan. 09, 2020. doi:10.1016/j.fct.2004.01.004.

AVANTAGGIATO, G.; et al. Assessment of the multi-mycotoxinbinding efficacy of a carbon/aluminosilicate-based product in an in vitro gastrointestinal model. Journal of Agricultural and Food Chemistry, v.55, p.4810-4819, 2007. Available from: <https:// pubs.acs.org/doi/abs/10.1021/jf0702803>. Accessed: Jan. 30, 2020. doi: $10.1021 /$ jf0702803.
AWAD, W. A. et al. In vitro effects of deoxynivalenol on small intestinal D-glucose uptake and absorption of deoxynivalenol across the isolated jejunal epithelium of laying hens. Poultry Science, v.86, p.15-20, 2007. Available from: <https://www. sciencedirect.com/science/article/pii/S0032579119423651>. Accessed: Apr. 10, 2020. doi: 10.1093/ps/86.1.15.

BASSO, K. M.; BRACARENSE, A. P. F. R. L. Explantes teciduais: um modelo redescoberto na experimentação animal. Semina: Ciências Agrárias, v.34, n.6, p.3951-3958, 2013. Available from: <http://www.uel.br/revistas/uel/index.php/semagrarias/ article/viewFile/15185/13964>. Accessed: Jan. 25, 2020. doi: 10.5433/1679-0359.2013v34n6Supl2p3951.

BRASIL, 2006. Portaria no. 130, 24 de maio de 2006. O Ministério da Agricultura, Pecuária e Abastecimento institui o Grupo de Trabalho sobre Micotoxinas em produtos destinados à alimentação animal. Diário Oficial da União da República Federativa do Brasil, Brasília, Distrito Federal, 25 de mai. 2006, seção 2, p.5. Available from: <https://www.jusbrasil. com.br/diarios/587415/pg-5-secao-2-diario-oficial-da-uniao-doude-25-05-2006>. Accessed: Jun. 15, 2020.

CHELI, F.; et al. Mycotoxin mechanisms of action and health impact: 'in vitro' or 'in vivo' tests, that is the question. World Mycotoxin Journal, v.8, n.5, p.573-589, 2015. Available from: $\quad<$ https://www.researchgate.net/publication/282513973_ Mycotoxin_mechanisms_of_action_and_health_impact_'_in vitro_'or_' in vivo_' tests that is the question $>$. Accessed: Jan. 30,2020 . doi: $10.3920 / \bar{W} M J 2014.1864$.

CLARK, J. M. The 3Rs in research: a contemporary approach to replacement, reduction and refinement. British Journal of Nutrition, v.120, n.1, p.1-7, 2018. Available from: <https:// pubmed.ncbi.nlm.nih.gov/29081302/>. Accessed: Jul. 04, 2021. doi: $10.1017 / \mathrm{S} 0007114517002227$.

COBB-VANTRESS. Broiler Performance \& Nutrition Supplement. Cobb-Vantress Inc., Siloam Springs, AR, 2018. Available from: <https://www.cobb-vantress.com/assets/CobbFiles/product-guides/bdc20a5443/70dec630-0abf-11e9-9c88c51e407c53ab.pdf>. Accessed: Jun. 07, 2020.

EUROPEAN FOOD SAFETY AUTHORITY - EFSA. Statement on the establishment of guidelines for the assessment of additives from the functional group 'substances for reduction of the contamination of feed by mycotoxins'. EFSA Journal, v.8, p.1693-1700, 2010. Available from: <https://www.efsa.europa.eu/en/efsajournal/ pub/1693 > . Accessed: Jan. 07, 2020. doi: 10.2903/j.efsa.2010.1693.

GARCIA, G. R. et al. Intestinal toxicity of deoxynivalenol is limited by Lactobacillus rhamnosus RC007 in pig jejunum explants. Archives of Toxicology, v.92, p.983-993, 2018. Available from: $<$ https://www.researchgate.net/publication/320108495_Intestinal_ toxicity_od_Deoxynivalenol_is_limited_by_Lactobacillus_ rhamnosus_RC007_in_pig_jejunum_explants>. Accessed: Jun. 10, 2020. doi: $10.1007 / \mathrm{s} 00204-017-\overline{2} 083-\mathrm{x}$.

GEREZ, J. R. et al. Low levels of chito-oligosaccharides are not effective in reducing deoxynivalenol toxicity in swine jejunal explants. Toxins, v.10, p.276-287, 2018. Available from: $<$ https:// www.mdpi.com/2072-6651/10/7/276>. Accessed: Jun. 03, 2020. doi: $10.3390 /$ toxins 10070276 .

GRATZ, S.; et al. Aflatoxin B binding by a mixture of Lactobacillus and Propionibacterium: in vitro versus ex vivo. 
Journal of Food Protection, v.68, p.2470-2474, 2005. Available from: < https://hub.hku.hk/handle/10722/178911>. Accessed: Oct. 09, 2020. doi: 10.4315/0362-028X-68.11.2470.

HALAWA, A. et al. Intestinal transport of deoxynivalenol across porcine small intestines. Archives of Animal Nutrition, v.67, p.134-146, 2013. Available from: <https://pubmed. ncbi.nlm.nih.gov/23521693/>. Accessed: Jan. 07, 2020. doi: 10.1080/1745039X.2013.776327.

JANSEN VAN RENSBURG, C. et al. In vitro and in vivo assessment of humic acid as an aflatoxin binder in broiler chickens. Poultry Science, v.85, p.1576-1583, 2006. Available from: $<$ https://pubmed.ncbi.nlm.nih.gov/16977843/>. Accessed: Jun. 30, 2021. doi: $10.1093 / \mathrm{ps} / 85.9 .1576$.

KOLAWOLE, O. et al. Comparative In Vitro Assessment of a Range of Commercial Feed Additives with Multiple Mycotoxin Binding Claims. Toxins, (Basel), v.11, p.659, 2019. Available from: $\quad<$ https://www.mdpi.com/2072-6651/11/11/659/htm/>. Accessed: Jun 30, 2021. doi: 10.3390/toxins 11110659 .

LUCIOLI, J. et al. The food contaminant deoxynivalenol activates the mitogen activated protein kinases in the intestine: Interest of ex vivo models as an alternative to in vivo experiments. Toxicon, v.66, p.31-36, 2013. Available from: $<$ https://pubmed.ncbi.nlm.nih.gov/23403092/>. Accessed: Oct. 11, 2020. doi: 10.1016/j.toxicon.2013.01.024.

MALLMANN, C. A. et al. Correlação entre o desempenho de aditivos anti-micotoxinas (AAM) para aves em testes in vitro e in vivo. Revista Brasileira de Ciência Avícola, v.9, p.176185, 2007. Available from: <https://www.lamic.ufsm.br/site/ publicacoes/category/3-fumonisinas?download $=56$ : correlacaoentre-o-desempenho-de-aditivos-anti-micotoxinas-aam-para-avesem-testes-in-vitro-e-in-vivo>. Accessed: Jan. 15, 2020.

MARCHIORO, A. et al. Effects of aflatoxins on performance and exocrine Pancreas of Broiler Chickens. Avian Diseases, v.57, p.280-284, 2013. Available from: <https://pubmed.ncbi.nlm.nih. gov/24689186/>. Accessed: Jul. 04, 2021. doi: 10.1637/10426101712-Reg.1.
NEIRINCKX, E. et al. Feasibility of the Ussing chamber technique for the determination of in vitro jejunal permeability of passively absorbed compounds in different animal species. Journal of Veterinary Pharmacology and Therapeutics, v.34, p.290-297, 2010. Available from: $<$ https://onlinelibrary.wiley.com/doi/abs/10 $.1111 / \mathrm{j} .1365-2885.2010 .01218 . \mathrm{x}>$. Accessed: Jan. 07, 2020. doi: 10.1111/j.1365-2885.2010.01218.x.

OGUZ, H. Detoxification of aflatoxin in poultry feed: a review from experimental trials. Lohmann Information, v.47, p.45-56, 2012. Available from: <https://drupal.aspergillus.co.uk/content/ detoxification-aflatoxin-poultry-feeda-review-experimentaltrials>. Accessed: Mar. 15, 2020.

THE UNITED STATES PHARMACOPEIA (USP XXII) THE NATIONAL FORMULARY (NF-XVII). p.1788-1789, 1990. Available from: <https://journals.sagepub.com/doi/10. 1177/875512259000600204>. Accessed: Jun. 07, 2020. doi: $10.1177 / 875512259000600204$.

THOMSON, A. et al. The Ussing chamber system for measuring intestinal permeability in health and disease. BMC Gastroenterology, v.19, p.98-99, 2019. Available from: <https:// bmcgastroenterol.biomedcentral.com/articles/10.1186/s12876019-1002-4>. Accessed: Apr. 20, 2020. doi: 10.1186/s12876-0191002-4.

YIANNIKOURIS, A. et al. Comparison of the sequestering properties of yeast cell wall extract and hydrated sodium calcium aluminosilicate in three in vitro models accounting for the animal physiological bioavailability of zearalenone. Food Additives \& Contaminants: Part A, v.30, p.1641-1650, 2013. Available from: $<$ https://pubmed.ncbi.nlm.nih.gov/23844575/>. Accessed: Jun. 07, 2020. doi: 10.1080/19440049.2013.809625.

ZHANG, B. et al. Dietary L-arginine inhibits intestinal Clostridium perfringens colonisation and attenuates intestinal mucosal injury in broiler chickens. British Journal of Nutrition, v.118, p.321-332, 2017. Available from: <https://europepmc.org/ article/pmc/pmc6080643>. Accessed: Oct. 09, 2020. doi: 10.1017/ S0007114517002094 